Gut, 1985, 26, 822-824

\title{
Therapeutic benefits from a poorly absorbed prednisolone enema in distal colitis
}

\author{
P B McINTYRE, F A MACRAE, L BERGHOUSE, J ENGLISH, \\ AND J E LENNARD-JONES
}

From St Mark's Hospital, London

SUMmary A double blind controlled trial has been conducted in 40 patients to compare the therapeutic effects of prednisolone metasulphobenzoate enemas with those of prednisolone-21phosphate enemas. Both enemas brought about improvement in symptoms and sigmoidoscopic appearances in more than $70 \%$ of patients treated. The absorption of prednisolone from the metasulphobenzoate enema in three patients was less than from the 21-phosphate enema. In view of the low plasma prednisolone concentrations obtained, there are theoretical advantages in using a poorly absorbed enema to avoid the possibility of systemic steroid effects in patients requiring long term steroid treatment.

Retention enemas containing prednisolone have been a standard treatment for distal ulcerative colitis for many years. ${ }^{1}$ Previous work has shown that significant plasma prednisolone concentrations result from the administration of an enema containing $20 \mathrm{mg}$ prednisolone as prednisolone-21-phosphate, in $100 \mathrm{ml}$ water. ${ }^{23}$ Although systemic side effects are rarely seen, the possibility exists that long term treatment with prednisolone-21-phosphate enemas may be detrimental. Lee and his colleagues ${ }^{3}$ reported low plasma levels of prednisolone after administration of an enema containing $20 \mathrm{mg}$ prednisolone as prednisolone metasulphobenzoate and postulated a local site of action. To test the clinical efficacy of these enemas we undertook a double blind controlled trial, comparing prednisolone-21-phosphate and prednisolone metasulphobenzoate enemas, in conjunction with further studies of prednisolone absorption after administration of both types of enema.

\section{Methods}

ABSORPTION STUDIES

Enemas containing $20 \mathrm{mg}$ prednisolone as prednisolone-21-phosphate or $20 \mathrm{mg}$ prednisolone as prednisolone metasulphobenzoate in $100 \mathrm{ml}$ water were given to each of three patients on separate days. Three other patients received an enema containing $60 \mathrm{mg}$ prednisolone as prednisolone Address for correspondence: Prof J E Lennard-Jones, St Marks Hospital, City Road, London EC1V 2PS.

Received for publication 21 September 1984. zoate in $100 \mathrm{ml}$ water. Oral or topical steroid preparations were not given for at least 24 hours before the test enema. Blood was removed for plasma prednisolone concentrations before, and 30 , $60,120,240$, and 360 , or 480 minutes after, enema administration. A rectal biopsy was taken at 360 or 480 minutes after the enema had been given.

\section{LABORATORY METHODS}

Blood samples were placed in lithium heparin tubes, centrifuged and the supernatant stored at $-20^{\circ} \mathrm{C}$ until analysis. Rectal biopsies were taken in the standard way, and washed with saline to remove debris, surface secretion and residual enema fluid before freezing at $-20^{\circ} \mathrm{C}$ until analysis. Plasma and tissue prednisolone concentrations were measured using a radioimmunoassay technique previously reported. ${ }^{4}$ The cross-reactivity of prednisolone metasulphobenzoate with the antiserum was $100 \%$ of that with prednisolone.

\section{CLINICAL TRIAL METHODS}

Forty outpatients with an exacerbation of previously diagnosed distal ulcerative colitis were admitted to the trial after giving informed consent. Each received a nightly enema for two weeks. Both prednisolone preparations were clear solutions packaged in identical plastic containers holding 100 $\mathrm{ml}$. The identity of the prednisolone salt received by each patient was retained by the hospital pharmacy and remained unknown to the patients and their doctors until after completion of the trial. Patient's 
symptoms, and the sigmoidoscopic and histological appearances of the rectal mucosa were documented before and after the treatment period and estimations made of haemoglobin levels and ESR. Sigmoidoscopic appearances were graded as: nonhaemorrhagic, score 0 ; haemorrhagic with bleeding on light contact with the sigmoidoscope, score 1, and haemorrhagic with spontaneous bleeding seen in front of the advancing sigmoidoscope, score 2. Histology was reviewed by a single observer who had no prior knowledge of the patients, or of the timing, relative to treatment, of the biopsies.

\section{Results}

\section{ABSORPTION STUDIES}

Table 1 shows peak plasma concentrations, area under the absorption curve and tissue levels for each of the three types of enema used. The Figure shows by the absorption curves for the $20 \mathrm{mg}$ prednisolone21-phosphate and prednisolone metasulphobenzoate enemas. Both the peak plasma concentrations and areas under the curve measured by a linear trapezoidal method were less after prednisolone metasulphobenzoate enemas than after prednisolone-21-phosphate enemas, confirming the findings of Lee et al. ${ }^{3}$ Indeed, comparable peak levels were only obtained after administration of $60 \mathrm{mg}$ prednisolone in the form of prednisolone metasulphobenzoate. Tissue levels showed a reciprocal pattern, being higher after prednisolone metasulphobenzoate than after prednisolone-21-phosphate.

\section{CLINICAL TRIAL}

Two patients failed to attend for their follow up appointment, and a third patient was diagnosed as having the solitary rectal ulcer syndrome on review of the histology. All three patients had received prednisolone-21-phosphate enemas. Table 2 shows

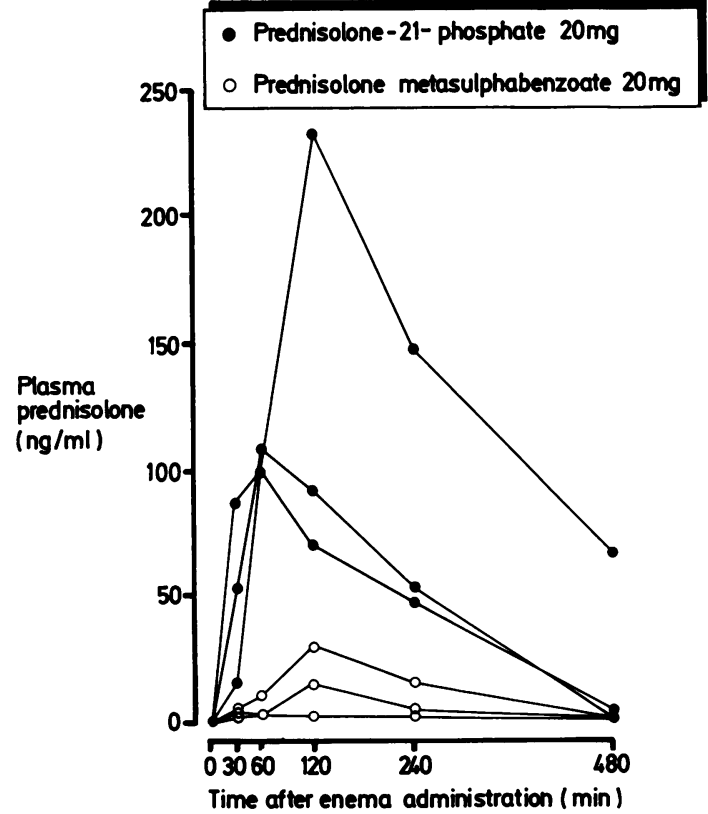

Figure Plasma prednisolone absorption curves obtained after the administration of $20 \mathrm{mg}$ prednisolone as either prednisolone-21-phosphate or prednisolone metasulphobenzoate.

the distribution of sex, age, and extent of disease in the two groups. Table 3 gives the results after treatment as judged by patient's symptoms, stool frequency, sigmoidoscopic score and histological appearance. Fourteen patients reported an improvement in their symptoms after prednisolone-21phosphate, compared with 15 after prednisolone metasulphobenzoate. After treatment with either enema, there was significant improvement, using

Table 1 Levels of prednisolone in plasma and in rectal biopsies after administration of retention enemas containing either prednisolone-21-phosphate or prednisolone metasulphobenzoate.

\begin{tabular}{|c|c|c|c|c|c|c|c|c|c|}
\hline \multirow[b]{2}{*}{ Patient } & \multicolumn{3}{|c|}{ Prednisolone-21-phosphate 20mg* } & \multicolumn{3}{|c|}{$\begin{array}{l}\text { Prednisolone } \\
\text { metasulphobenzoate } 20 \mathrm{mg}^{*}\end{array}$} & \multicolumn{3}{|c|}{$\begin{array}{l}\text { Prednisolone } \\
\text { metasulphobenzoate } 60 \mathrm{mg}^{*}\end{array}$} \\
\hline & $\begin{array}{l}\text { Peak } \\
\text { level } \\
(\text { ng/ml) }\end{array}$ & $\begin{array}{l}\text { Area under } \\
\text { the curve } \\
(\text { ng/ml } h)\end{array}$ & $\begin{array}{l}\text { Tissue } \\
\text { level } \\
\text { (ng/g) }\end{array}$ & $\begin{array}{l}\text { Peak } \\
\text { level } \\
\text { (ng/ml) }\end{array}$ & $\begin{array}{l}\text { Area under } \\
\text { the curve } \\
\text { (ng/ml h) }\end{array}$ & $\begin{array}{l}\text { Tissue } \\
\text { level } \\
\text { (ng/g) }\end{array}$ & $\begin{array}{l}\text { Peak } \\
\text { level } \\
\text { (ng/ml) }\end{array}$ & $\begin{array}{l}\text { Area under } \\
\text { the curve } \\
(\mathrm{ng} / \mathrm{ml} \mathrm{h})\end{array}$ & $\begin{array}{l}\text { Tissue } \\
\text { level } \\
\text { ( } \mu g / g)\end{array}$ \\
\hline 1 & 100 & 341 & 39 & 16 & 45 & Not done & & & \\
\hline 2 & 235 & 1051 & 80 & 32 & 107 & 304 & & & \\
\hline 3 & 109 & 406 & 12 & 2 & 11 & 269 & & & \\
\hline 4 & & & & & & & 200 & 1000 & 1.56 \\
\hline 5 & & & & & & & 184 & 845 & 1.48 \\
\hline 6 & & & & & & & 56 & 51 & 2.06 \\
\hline
\end{tabular}

${ }^{*}$ measured as prednisolone. 
Table 2 Comparability of the two treatment groups.

\begin{tabular}{lll}
\hline & $\begin{array}{l}\text { Prednisolone } \\
\text { 21-phosphate }\end{array}$ & $\begin{array}{l}\text { Prednisolone } \\
\text { metasulphobenzoate }\end{array}$ \\
\hline Male:female & $14: 6$ & $11: 9$ \\
Age range (years) & $22-80$ & $22-72$ \\
Age mean \pm SD & $45 \pm 16$ & $43 \pm 6$ \\
Proctitis & 10 & 10 \\
Proctocolitis & 10 & 10 \\
\hline
\end{tabular}

Student's $t$ test for paired data, in stool frequency and sigmoidoscopic score. There was no difference between the two groups.

\section{Discussion}

We have shown that a poorly absorbed steroid enema which presumably acts at the site of application is as effective as a well absorbed enema which produces high plasma prednisolone values. These

Table 3 Results of treatment for 2 weeks with retention enemas containing prednisolone, $20 \mathrm{mg}$, as either the 21-phosphate or metasulphobenzoate ester.

\begin{tabular}{|c|c|c|}
\hline & $\begin{array}{l}\text { Prednisolone } \\
\text { 21-phosphate }\end{array}$ & $\begin{array}{l}\text { Prednisolone } \\
\text { metasulphobenzoate }\end{array}$ \\
\hline \multicolumn{3}{|c|}{ Symptoms after treatment } \\
\hline Symptom-free & 5 & 2 \\
\hline Improved & 9 & 13 \\
\hline No change & 2 & 5 \\
\hline Worse & 1 & 0 \\
\hline Withdrawn & 3 & 0 \\
\hline \multicolumn{3}{|l|}{ Stool frequency } \\
\hline Mean \pm SEM & & \\
\hline Before & $4 \cdot 5 \pm 0 \cdot 6$ & $4 \cdot 5 \pm 0 \cdot 5$ \\
\hline After & $2 \cdot 6 \pm 0 \cdot 6^{*}$ & $2 \cdot 7 \pm 0 \cdot 3 \dagger$ \\
\hline \multicolumn{3}{|c|}{ Sigmoidoscopy score } \\
\hline Total (mean) & & \\
\hline Before & $25(1 \cdot 34)$ & $31(1 \cdot 6)$ \\
\hline After & $13(0.7)^{\dagger}$ & $11(0.6) \dagger$ \\
\hline \multicolumn{3}{|l|}{ Histology } \\
\hline Improved & 6 & 6 \\
\hline No change & 10 & 11 \\
\hline Worse & 1 & 2 \\
\hline No biopsy & 0 & 1 \\
\hline
\end{tabular}

results are interesting, but do not help solve the question of the ultimate site of action of prednisolone in ulcerative colitis. The marked difference in tissue levels is probably explained by the good absorption of prednisolone through the rectal mucosa after a prednisolone-21-phosphate enema, while this does not occur after prednisolone metasulphobenzoate, and the tissue levels rise progressively.

Previous studies ${ }^{5}$ have shown little suppression of the adrenal cortex after chronic treatment with prednisolone enemas though there are a few patients who complain of troublesome fluid retention, weight gain, 'mooning' of the face or acne while receiving long term treatment. Patients whose disease requires such long term treatment to maintain remission of their inflammatory bowel disease or those at particular risk of side effects such as those with a diabetic tendency could avoid the risks of adverse effects by using poorly absorbed enemas.

The authors wish to thank Pharmax Laboratories who prepared and packaged the enemas used in this trial. L Berghouse thanks the Sir Halley Stewart Trust for financial support.

\section{References}

1 Matts SGF. Intra-rectal treatment of 100 cases of ulcerative colitis with prednisolone-21-phosphate enemata. Br Med J 1961; 1: 165-8.

2 Powell-Tuck J, Lennard-Jones JE, May CS, Wilson CG, Paterson JW. Plasma prednisolone levels after administration of prednisolone-21-phosphate as a retention enema in colitis. $\mathrm{Br}$ Med J 1976; 1: 193-5.

3 Lee DAH, Taylor M, James VHT, Walker G. Rectally administered prednisolone - evidence for a predominately local action. Gut 1980; 21: 215-8.

4 Chakraborty J, English J, Marks V, Dumasia MC, Chapman DJ. A radioimmunassay method for prednisolone: comparison with competitive protein binding method. Br J Clin Pharmacol 1976; 3: 903-6.

5 Lee DAH, Taylor GM, James VHT. Walker G. Plasma prednisolone levels and adrenocortical responsiveness after administration of prednisolone-21phosphate as a retention enema. Gut 1979; 20: 349-55. 